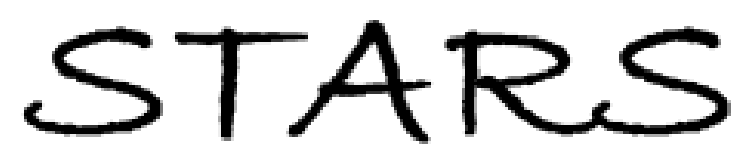

University of Central Florida

STARS

6-1-2015

\title{
Women at a Music Festival: Biological Sex Defining Motivation and Behavioral Intentions
}

Robertico R. Croes

University of Central Florida, robertico.croes@ucf.edu

Seung Hyan Lee

Part of the Hospitality Administration and Management Commons, and the Tourism and Travel Commons

Find similar works at: https://stars.library.ucf.edu/rosenscholar

University of Central Florida Libraries http://library.ucf.edu

This Paper is brought to you for free and open access by the Rosen College of Hospitality Management at STARS. It has been accepted for inclusion in Rosen Faculty Scholarship and Creative Works by an authorized administrator of STARS. For more information, please contact STARS@ucf.edu.

\section{Original Citation}

Croes, R. and Lee, S. (2015). Women at a Music Festival: Biological Sex defining Motivation and behavioral intentions. Event Management, 19(2), 275-289.

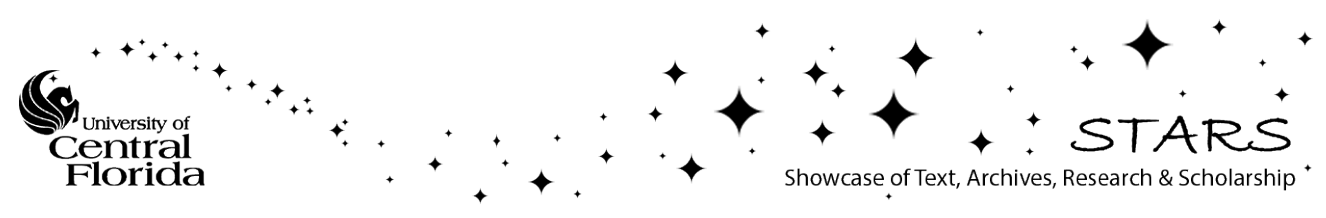




\title{
WOMEN AT A MUSIC FESTIVAL: BIOLOGICAL SEX DEFINING MOTIVATION AND BEHAVIORAL INTENTIONS
}

\author{
ROBERTICO CROES* AND SEUNG HYUN LEE† \\ *Tourism, Events and Attractions Department, Rosen College of Hospitality Management, University of \\ Central Florida, Orlando, FL, USA \\ †School of Hospitality Leadership, East Carolina University, Greenville, NC, USA
}

This study aims to assess whether biological sex impacts motivation and experience at a music festival in Curacao and is premised on different consumption behavior induced by biological sex. Differences in motivations and behavioral intentions based on biological sex were observed. The study further revealed that biological sex plays an important role in framing the experience and behavior intentions of the female segment. This finding is relevant as females are becoming an important mainstream at music festivals and travel and leisure consumers. Biological sex as a predictor of motivation and behavioral intentions has wider effects than just increasing demand; it may deeply shape travel and leisure patterns. Failure to consider this finding could lead to dissatisfaction and missed opportunities in product offerings.

Key words: Experience; Female; Loyalty; Motivation; Music festival; Satisfaction; Curacao

Introduction

The purpose of this study is twofold. First, the study explores whether females and males have different motivations for attending music festivals, and second, the study examines whether biological sex moderates the relationship between motivation, satisfaction, and behavioral intention. The extant literature pertaining to festivals and festival motivations reveals the application of the travel motivation framework (Getz, 1991; Nicholson \& Pearce, 2001;
Woo, Yolal, Cetinel, \& Uysal, 2011). This framework assumes that motive is a multidimensional construct, and that motive is an antecedent of satisfaction and behavioral intention. Although a significant number of studies have examined festival and motivations, very few studies have investigated the role of music festivals in shaping motivation towards a destination. Similarly, few studies have explored the propositions that females' and males' motivation is different, and that the relationship between motivation and behavioral intention may be intervened by biological sex. 
Motivation is a construct that has received heightened attention. The reason is that motivation is critical in understanding and directing marketing and segmentation and, hence, demands. The ability of identifying needs and wants of customers and aligning these with tourist offerings is crucial in determining destinations' competitiveness (Croes, 2011). Therefore, it is important to understand the construct of motivation and how this motivation is linked to a festival. Foundationally, motivation is in between a person and a set of activities, and motivation is the driving force connecting the person with an activity. As a driving force, motivation consists of two components: its origin (particularly properties of where it is coming from) and the consequences of the force on a person's behavior (Michaelson, 2005). Thus, understanding how the characteristics of an activity are integrated in a person's behavior is the essence of investigating motivation.

The activity that this study will focus on is music festivals. What motivates the consumption of festivals is, therefore, the crux of this study. Tourism studies assumed in the past that motivation and behavior are not contingent on biological sex; in other words, female and male motivations and behavior are the same (Jönsson \& Devonish, 2008; Plangmarn, Mujtaba, \& Pirani, 2012). Recently, however, some empirical studies have questioned this assumption with their findings (Jensen, 2011; Reynolds \& Hritz, 2012). Consequently, marketing assumptions embedded in the male view of what is appealing about a destination may not hold for the female market. Research in tourism needs further testing of the proposition that female traveler motivation and behavior are different from males.

Further inquiry in the impact of biological sex on motivation is founded on two considerations. First, women have become a powerful player in fueling consumption in the globalized world, and as women become more financially independent, more educated, and more mobile, the upward trend of female consumption is expected to continue in the future (Warnick \& Chen, 2008), infusing changing participation patterns in leisure and travel (Collins \& Tisdell, 2002; Francese, 2004). Despite the growing importance of the female segment, the understanding of female needs and wants in the literature and business practices is surprisingly lacking, leading tourism organizations to underestimate and undervalue the female consumer (Silverstein \& Sayre, 2009).

Second, the recognition that males and females are different in motivation and behavior is undergirded in women's development theory (i.e., unlike the search for separation as the hallmark of males' development, connection is the guiding principle for female growth) (Miller, 1976). Females seem more attuned to connection while males seem more attuned to differentiation. The tourism research landscape seems lacking in a comprehensive understanding of female desires, motivation, and experiences. Tourism research has neither been able to pay enough attention in moderating the experiential dimension of travel by biological sex at a time when clear shifting patterns in leisure and travel towards a quest for organic and authentic experience occur (Florida, 2002).

One of the venues where an authentic and organic experience can be found is the music scene. Florida (2002) states, "One of the last areas of social life where a modicum of authenticity can be found is the music scene” (p. 187). However, the generalization of desires embedded in the previously mentioned studies denies the possibility that males and females might entertain different desires and experiences at music scenes. Music festivals have become a hallmark of a repositioning process among destinations, especially for small island destinations (Croes, Rivera, \& Semrad, 2010; Getz, 2010). Destinations have been searching for new avenues to maintain competitiveness due to global pressures emanating from new destinations, as well as changing demographics and lifestyles. In searching for new avenues, the consumption of festivals has surged significantly during the past decade (Getz, 2010; Leenders, 2010; Thrane, 2002).

This study is grounded in the centrality of desire to travel, while assuming that desires and experience are shaped by biological sex. Departing from these central tenets, the study investigates the motivations to attend a music festival, and how motivations impact experience. Finally, the impact will be related to intention, assessing potential multiple outcomes in terms of behavior. The study will therefore investigate three interrelated questions: (1) Is music a significant motivation to visit a destination? (2) Are female and male motivations attending a music festival different? (3) Does biological 
sex moderate the relationship between motivation and behavior intention?

The study focuses on a music festival in Curacao. Curacao is a small island destination attempting to reinvent itself through tourism development. Tourism development in Curacao has been slow, however, in gaining traction in the island's economy (Croes, 2011). In 2011, the island received 390,000 international visitors generating US\$540 million in tourism receipts (Central Bureau of Statistics, 2011; World Bank, 2011). In 2010, Fundacion Bon Intencion (FBI), a completely privately funded initiative, organized the first Curacao North Sea jazz Festival (CNSJF), aiming at rising tourist arrivals through a high-quality music festival (Croes et al., 2010). While tourists are drawn to the island for a variety of reasons, music festivals retain unique characteristics that set it apart from other tourism activities on the island. The anatomy of the event, including its performers, venue, services, and attendees, has made the festival a major social event that represents the heritage and spirit of the destination. Yet, there is a dearth of studies investigating music festivals in small island destinations.

The study adds building blocks to the descriptive stage of tourism motivation theory. These building blocks are related to females' desires and experiences. If travel is explained by females' desires and experiences, then the design and configuration of offerings would be impacted together with the framing of marketing contents. The contribution of this study is fourfold: (1) it empirically tests the sameness of motivation and experience between females and males; (2) it links motivation and behavioral intentions in female travel studies; (3) it employs the context of music festival as an underresearched area in female travel studies; and (4) it focuses on a small island destination as the venue for the festival.

The remainder of the study is organized as follows. The next section explores the debate regarding biological sex as a variable and its impact on travel consumer motivation and behavior. The literature will also assess the relevance of music festival as an important experiential venue and will discuss the motivation and behavioral intention studies. The third section will describe the methodological approach, while the following section will discuss the results of the study. The final section will dwell upon the conclusion and implications of the study and will suggest future research areas.

\section{Literature Review}

The researchers engaged in a thorough search through EBSCO Hospitality and Tourism Complete search. The search was conducted keying the words "motivation or motive" and "women or female or gender." Motivation is defined as the specific direction of needs to activities, while motive is the generic driving force that integrates a person's behavior, such as achievement motive (Gnoth, 1997). Biological sex references comparisons of physical characteristics based on sex, while gender denotes sociocultural characteristics and behaviors that a society associates with men and women (Ulrich, 2013). This study focuses on biological sex as an intervening variable explaining the relationship motivation, satisfaction, and behavioral intention. The search covered the years from 2000 to 2013, and identified a total of 117 peer-reviewed publications. An additional filter was used adding the term "travel or tourism or leisure." The filter weeded out 60 articles for a remaining 57 articles.

A thorough reading of the abstracts revealed that as of February 20, 2013 only 23 articles contained motivation, gender, and travel as clear variables, and are revealed in parentheses: Asia Pacific Journal of Tourism Research $(n=1)$, Current Issues in Tourism $(n=2)$, International Journal of Tourism Research $(n=1)$, Journal of China Tourism Research ( $n=1)$, Journal of Hospitality \& Leisure Marketing $(n=1)$, Journal of Sport \& Tourism $(n=1)$, Journal of Travel \& Tourism Marketing $(n=3)$, Journal of Travel Research $(n=1)$, Journal of Vacation Marketing $(n=1)$, Sport in Society $(n=1)$, Studies in Physical Culture \& Tourism $(n=1)$, Tourism \& Hospitality Research $(n=1)$, Tourism ( $n=1)$, Tourism Analysis $(n=3)$, Tourism Economic $(n=2)$, Tourism Management $(n=1)$, Tourism Review International $(n=1)$.

\section{Motivations for Attending Music Festivals}

Music festivals are recurrent theme and cultural celebrations of short duration. This social practice aims as a tourist attraction, image building, community identity, and even destination repositioning 
(Bowen \& Daniels, 2005; Croes et al. 2010; Getz, 2010; Gursoy, Kim, \& Uysal, 2004). While music festivals have proliferated in recent times, there are only a few studies focusing specifically on music festivals (Bowen \& Daniels, 2005; Faulkner, Fredline, Larson, \& Tomljenovic, 1999; Formica \& Uysal, 1996; Gelder \& Robinson, 2009; Saleh \& Ryan, 1993; Thrane, 2002). Music festivals are unique special events where music is the central theme and where generally numerous performances from different artists are involved. Music festivals have become, in the postmodern era, an opportunity where individuals shop for lifestyle experience either to shape or reconfirm their identity (Allen, O’Toole, McDonnell, \& Harris, 2002; Leenders, 2010; Richards, 2010). Because of this particularity, music festivals can attract people for a variety of reasons (Bowen \& Daniels, 2005) but these reasons have not been fully explored in the literature.

Most studies examining reasons for attending a music festival display similar features (Bowen \& Daniels, 2005; Crompton \& McKay, 1997; Faulkner et al., 1999; Formica \& Uysal, 1996; Nicholson \& Pearce, 2001; Pegg \& Patterson, 2010; Thrane, 2002). First, these studies are heavily influenced by Crompton's (1979) nine motivational domains, such as escape from a perceived mundane environment, exploration and evaluation of self, relaxation, prestige, regression, enhancement of kinship relationships, facilitation of social interaction, novelty, and education. Second, these studies employ a factor analysis to identify the motivations. And, third, several statistical procedures are used to estimate the relationship between identified factors in motivation, sociodemographic variables, and satisfaction levels.

Music festivals attract an audience for a variety of reasons. Crompton and McKay (1997) described the multiplicity of tourists' motives at a festival setting that may occur at both the individual and the aggregate levels of analysis, and identified socialization as the desire to interact with others at the site. A number of studies underscored the relevance of socialization (e.g., Change \& Chiang, 2006; Formica \& Uysal, 1996; C. K. Lee, Lee, \& Wicks, 2004; Mohr, Backman, Gahan, \& Backman, 1993; Nicholson \& Pearce, 2001; Scott, 1996; Smith \& Costello, 2009; Uysal, Gahan, \& Martin, 1993; Yolal, Cetinel, \& Uysal, 2009). Another powerful motive present in the literature is escape (Gelder \& Robinson, 2009; Mohr et al., 1993; Nicholson \& Pearce, 2001; C. K. Lee et al., 2004; Schneider \& Backman, 1996; Scott, 1996; Uysal et al., 1993; Van Zyl \& Botha, 2004; Yolal et al., 2009).

Some attendees participate in a music festival because they are inspired by current musical artists while others are motivated for the reason that the festival increases knowledge of local culture. For others, the social element plays an important role that they come to join their friends and family (Schofield \& Thompson, 2007) or simply attend the festival while in search of something to do at a destination or to feel socially included (Bowen \& Daniels, 2005). Formica and Uysal (1996) identified five dimensions of motivations for jazz festival attendance, including excitement and thrills, socialization, entertainment, event novelty, and family togetherness.

While visitors attend a music festival for different needs and wants, the understanding of these motivations is critical for event managers, festival organizers, and destination marketers. Segmenting festival markets through motivations enables event managers to identify the strengths and opportunities of each market and helps guarantee their satisfaction (C. K. Lee \& Lee, 2001). Especially in the context of a new emerging female market, if organizers have an ability to identify motivations, these motivations can be used to facilitate the effectiveness in marketing activities and to support the expansion of the tourist base of a destination (Crompton \& McKay, 1997). For example, practical settings, contexts, and advertising in a festival can be amended to facilitate fulfillment of attendees' motivations. In addition, information regarding patron motivations can also be used to appeal to sponsors, who are becoming an increasingly important part of event funding (Bowen \& Daniels, 2005; Crompton \& McKay, 1997; Oakes, 2003). Thus, understanding visitors' motivation for attending festivals and events should be the primary goal of festival managers (Getz, 1993; Iso-Ahola, 1982; Scott, 1996).

\section{Females at Music Venues}

Music festivals provide a unique opportunity for participating in the cocreation process, and female travelers seem to seek social opportunities at music festivals (Bowen \& Daniels, 2005; Pegg \& Patterson, 
2010; Staggenborg, Eder, \& Sudderth, 1994; Thrane, 2002). Most research on festivals addresses economic impacts (Pegg \& Patterson, 2010; Thrane, 2002). There are only a handful of studies investigating female motivation for attending and participating in music festivals (Gelder \& Robinson, 2009; Yolal et al., 2009). The relevance of female participation in a music festival is only slowly being recognized. Still, one of the foundational works of Getz (2010) on the nature and scope of festival studies is oblivious to the role of females in bolstering festival tourism.

Palan (2001) claims biological sex is a good predictor for explaining differences in attitudes and behavior. Yet, the tourism literature is slow to adhere to Palan's claim. The tourism landscapes defined by imagery and narratives are mainly dominated by a male-centered view of the world (Enloe, 1989; Graburn \& Jafar, 1991; Pritchard \& Morgan, 2000). The male-centered travel world has permeated the leisure/travel studies and has defined the tourism landscapes (Irigaray, 1993; Pritchard \& Morgan, 2000). Fullagar (2002) also echoes the claim of the centrality of the male dominant travel perspective. This travel perspective has privileged masculine experience as a universal norm, thereby resulting in women's different experiences, subjectivities, and desires that have been suppressed (Fullagar, 2002). Over time, the male-centered world seems to be subsiding, however, to include a new vision that women are not a simple extension of male motivation, expectation, and experience (CockburnWootten, Friend, \& McIntosh, 2006; Fullagar, 2002; Gibson, 2005; Reisinger \& Mavondo, 2004).

Biological sex is typically listed together with other demographic factors, such as age, level of education, nationality, trip attributes, ethnicity, and social class as a motive or predictor of travel experience (Barber, Taylor, \& Deale, 2010; Beerli \& Marín, 2004; Kollmuss \& Agyeman, 2002; MarzoNavarro \& Pedraja-Iglesias, 2009). Most studies, however, do not articulate biological sex as a central discriminant variable in explaining behavior. Where biological sex enjoys centrality in the research design, results did not show consistent findings as to the relevance of biological sex as a variable explaining variance in behavior in studies. For example, Change and Chiang (2006), Craggs and Schofield (2009), De Menezes and Moniz (2011), Hallab, Price, and Fourniert (2006), Hinch and Walker (2005), Ignatov and Smith (2006), and Mohsin (2008) concur that female travelers entertain different motivation and experience than males. Female travel experience involves a social desire that connects women with local people or other travelers, thus an experiential authentic experience becomes an important factor (Fullagar, 2002; McNamara \& Prideaux, 2010). Other motivational factors include knowledge, prestige, enhancement of social relationships, and rest (Li, Wen, \& Leung, 2011). While these studies considered biological sex as one of the variables, most of these studies were not able to articulate how important sex was as an explanatory variable of behavior.

Other competing results are found in studies of Andreu, Kozac, Avci, and Cifter (2005), Beerli and Martin (2004), Jönsson and Devonish (2008), and Tkaczynski and Prebensen (2012). Beerli and Martin (2004), for example, found that country of origin seems to matter more than sex in the case of tourist motivations of visiting the island of Lanzarote (Canary Islands). Similarly, Jönsson and Devonish (2008) investigated whether there are differences in motivation between male and female tourists traveling to Barbados and found that being male or female does not significantly influence tourist motivations to visit Barbados. Tkaczynski and Prebensen (2012) classified French residents who exhibit an interest in nature-based vacations and in visiting Norway into three valid groups. These segments differed based on the identified variables but sex was not found to be a significant indicator.

The results in the literature are thus far mixed, thereby preventing travel consumer behavior research to gain more insights and understanding of the relevance of sex in explaining variance in attitude, expectations, and behavior. The tourism literature seems still permeated by a malecentered view of travel motivation and experience. For example, in the study conducted by Barber et al. (2010) regarding the influence of a number of demographic factors in wine consumption, females are more likely to be emotionally involved and passionate about environmental circumstances and thus more likely to support environmentally sustainable wine production. However, in providing recommendations to wine marketing professionals, the authors only referenced the importance of male consumers in their recommendations. 
Females have become the primary target market for many travel businesses (Collins \& Tisdell, 2002; $\mathrm{Li}$ et al., 2011). The increasing attention on understanding female travelers has two premises. First, the more women receive a better education and have improved access to employment opportunities, the more they have the time, finances, and social networks to undertake travel (Nitto \& Shiozaki, 2001; Warnick \& Chen, 2008). Second, female travelers have a strong purchasing power and exhibit a greater intent to spend more money at the destination than do male travelers (Brudney, 2002; Craggs \& Schofield, 2009). As females increasingly engage in travel as consumers, a heightened attention has been paid to travel motivation of female travelers. Understanding female travel motivation and how this motivation impacts marketing information processing and evaluation by females has become crucial for competitiveness (Kim, Lehto, \& Morrison, 2007).

In sum, although motivations of festival attendance have been well studied (Crompton \& McKay, 1997; C. K. Lee et al., 2004; Nicholson \& Pearce, 2001), a greater understanding of visitor motivations as related to music festival attendance is needed (Bowen \& Daniels, 2005). The results of studies addressing sex are mixed in relation to motivation at a music festival. Some studies found that females have different motivations than males (Pegg \& Patterson, 2010; Yolal et al., 2009) while others found either marginal differences (Bowen \& Daniels, 2005) or no difference at all (Jönsson \& Devonish, 2008).

\section{Satisfaction and Behavioral Loyalty}

Motivations are closely aligned with satisfaction. Satisfaction in conjunction with motivation seems relevant in event design and management (Crompton \& McKay, 1997). The overall satisfaction is defined as "an overall evaluation based on the total purchase and consumption experience with a good or service over time" (Anderson, Fornell, \& Lehmann, 1994, p. 54). Dann (1981) asserted that it makes little sense to study satisfaction in isolation from motivation. In other words, when festivals fulfill needs and motivations of attendees, attendees will be satisfied with the festivals. Individuals perceive a leisure activity as a potential satisfaction producer because the activity may provide certain intrinsic rewards and an escape from the routine environment (Iso-Ahola, 1982).
These internal psychological perspectives may stimulate and reinforce inherent push motivations (McGehee, Loker-Murphy, \& Uysal, 1996).

Previous studies on festivals support a positive relationship between satisfaction and behavioral loyalty (Baker \& Crompton, 2000; Cole \& Illum, 2006; S. Y. Lee, Petrick, \& Crompton, 2007; Thrane, 2002). For example, Schofield and Thompson (2007) emphasize the importance of pinpointing festival visitor motivations and measuring the performance of festivals. In relation to visitor satisfaction and behavioral intention, festival managers are recommended to identify factors that affect visitor motivation and their experiential outcomes. However, most festival studies either neglect the discussion of a causal relationship or defined behavioral intentions only in terms of intent to return as the outcome variable.

\section{Hypotheses Development}

The current study determines a causal relationship between different music festival motivations, satisfaction, and behavioral loyalty. Crompton and McKay (1997) argued that motivations occur before the experience and satisfaction after it, so motivations can be considered antecedents of satisfaction. Also, satisfaction can have a direct impact on behavioral loyalty. Yoon and Uysal (2005) investigated the causal relationships among the push and pull motivations, satisfaction, and destination loyalty. Travel push motivation has a positively direct relationship with destination loyalty. In other words, internal psychological motivations (e.g., relaxation, family togetherness, and safety and fun) directly influence behavioral loyalty. Yet their study lacks how different motivations affect behavioral loyalty.

Motivation in the current study is classified into music and social factors. At a music festival setting, these factors are measured as what attracts and motivates individuals to come to the festival. Music as motivation stems from the travel motivation framework, and social factors are embedded in relational theory. These two frameworks complement each other in providing insights into the relationship motivation-satisfaction-loyalty moderated by biological sex. Evolutionary and consumer research asserts that females and males entertain different habits, practices, and preferences that resonate in their consumption behavior (Griskevicius \& Kenrick, 2013). 
Beyond the mere identification of motivations of festival attending, there is a dearth in the literature exploring the relationship with behavioral intention, especially targeting the female market. Since motivations sought at one festival are likely to differ from those sought at another festival (Scott, 1996), audience analysis at a music festival setting needs to be explored, especially the relationship to visitor satisfaction and loyalty. In addition, the tourism literature seems lacking in providing an understanding of how music festivals are intertwined with motivations and behavior intention of female travelers.

Based on the previous discussion, the following hypotheses were derived:

H1: Females and males have different motivation in attending a music festival.

H2: Biological sex moderates the relationship among motivations, satisfaction, and loyalty at a music festival.

\section{Methodology}

\section{Case Selection}

This study aims to identify motivations of female travelers and investigates the relationship between motivation and behavior intention in attending a music festival as it pertains to a specific music festival in Curacao. Curacao is a small island destination located in the Caribbean, and tourism has had a major impact on the island's economic growth and development over the last half century. Tourists have been mainly drawn to the small island for its sun, sea, and sand product but the island has been seeking new and unique product offerings to enhance experiences of tourists (Croes et al., 2010). In this shift, cultural entities and events play a stronger role in attracting visitors to the island. Thus, music festivals have been promoted as a quest for steering Curacao's products and services towards more experiential and relational experiences. However, there is a dearth of studies pertaining to the impact of music festivals in small island destinations.

\section{Study Design}

Several constructs were employed to investigate proposed hypotheses: motivations related to music and social elements, satisfaction, and behavioral intention. A questionnaire was developed based on the literature. The three items for music motivation were adopted from Thrane's (2002) study (e.g., "music is the motive for attending the festival"). The item for social motivation was adopted from Bowen and Daniels's (2005) study (e.g., "my motive for attending the festival is to join my friends/family"). Behavioral intentions were defined as intention to come back, provide a good reference, encourage friends and family; be the first choice; and recommend (Cronin \& Taylor, 1992; Oppermann, 2000; Zeithaml, Berry, \& Parasuraman, 1996). Five items for behavioral intention were employed in the study (e.g., "I have the intention of coming back to the festival next year"). A 7-point Likert scale was used ranging from 1 (completely disagree) to 7 (completely agree). A single item was used to encompass one's overall satisfaction (e.g., "overall, how satisfied were you with the services experienced at this festival?”), ranging from 1 (very dissatisfied) to 7 (very satisfied). Lastly, biological sex was measured based on participant self-identification and reporting.

\section{Sampling Procedure}

For $t$ tests, group sizes of more than 30 responses assure desired power levels (Hair, Black, Babin, \& Anderson, 2010). Also, the recommended rule of thumb for determining sample sizes for regression analysis is $N \geq 104+m$, where $N$ is the minimum number of subjects and $m$ denotes the number of predictors. The total number of surveys was targeted to be a minimum of 111 with seven independent variables with group sizes of more than 30 responses between males and females. A deliberate effort was made to obtain a representative sample of this particular captive population present at the CNSJF. A purposive sampling technique was used to identify respondents of the targeted population (Kerlinger, 1992).

\section{Data Collection}

The survey was collected at the Curacao North Sea Jazz Festival (CNSJF) on September 3 and 4, 2010. CNSJF was held for 2 days and drew famous artists performing in a wide range of music genres. For data collection, students from a local university 
were trained on survey instrument, strategies, and data collection. The organizer of the CNSJF made sure the survey collection did not interfere with attendees' experience. Thus, only certain areas were allowed for administering the surveys, such as sitting areas near restrooms and restaurants. As an incentive in soliciting survey participants, respondents were allowed to participate in a raffle for a weekend stay at a local hotel. The data collection procedure yielded 216 valid responses.

\section{Data Analysis}

The data from the survey were assessed through SPSS 17.0. The analysis comprised three steps. First, descriptive analysis was conducted to establish the demographic profile of the respondents. Second, $t$ tests were employed to determine the differences in motivation between females and males. Finally, simultaneous multiple regressions were carried out to examine the impact of biological sex on motivation, satisfaction, and behavioral intentions. Prior to conducting the regression analysis, several tests were conducted to determine if the models were trustworthy. A scatter plot of the residuals was employed as well as formal testing to verify that all the assumptions of the linear regression were met (linearity, normality, independence, homoscedasticity, and multicollinearity).

\section{Results}

\section{Sample Profile}

The demographic profile of the sample is shown in Table 1. A total of 216 surveys were collected. Taking into account that the total number of attendees based on ticket sales was 10,600 for the 2-day event, the survey represented $2.1 \%$ of the total sales. Most of the respondents were from the Netherlands and Suriname (60\%), followed by the US (16\%) and Aruba (6\%). Eighty-six percent of respondents came specifically to attend the festival. Fifty-two percent of respondents were female. In addition, the respondents had comparable income across income levels; $36 \%$ of them had a household income of $\$ 50,000$ or higher. Respondents revealed enjoying a high level of education as $83 \%$ of them had an undergraduate degree or higher. The distribution of
Table 1

Demographic Profile

\begin{tabular}{|c|c|c|}
\hline & Frequency & Percent \\
\hline \multicolumn{3}{|l|}{ Country of origin } \\
\hline Netherlands & 24 & $30 \%$ \\
\hline Surinam & 24 & $30 \%$ \\
\hline United States & 13 & $16 \%$ \\
\hline Aruba & 5 & $6 \%$ \\
\hline Bonaire & 2 & $3 \%$ \\
\hline Colombia & 2 & $3 \%$ \\
\hline Other & 9 & $11 \%$ \\
\hline \multicolumn{3}{|l|}{ Primary purpose } \\
\hline Festival & 65 & $86 \%$ \\
\hline Visit family \& friends & 7 & $9 \%$ \\
\hline Sun \& beach tourism & 3 & $4 \%$ \\
\hline Shopping & 1 & $1 \%$ \\
\hline \multicolumn{3}{|l|}{ Gender } \\
\hline Male & 98 & $48 \%$ \\
\hline Female & 108 & $52 \%$ \\
\hline \multicolumn{3}{|l|}{ Income } \\
\hline Under \$25,000 & 19 & $10 \%$ \\
\hline$\$ 25,000-\$ 29,999$ & 20 & $10 \%$ \\
\hline$\$ 30,000-\$ 39,999$ & 21 & $11 \%$ \\
\hline$\$ 40,000-\$ 49,999$ & 21 & $11 \%$ \\
\hline$\$ 50,000-\$ 74,999$ & 26 & $13 \%$ \\
\hline$\$ 75,000-\$ 99,999$ & 25 & $13 \%$ \\
\hline$\$ 100,000$ \& over & 20 & $10 \%$ \\
\hline \multicolumn{3}{|l|}{ Education } \\
\hline High school & 27 & $13 \%$ \\
\hline Undergraduate degree & 97 & $48 \%$ \\
\hline Master or doctorate & 70 & $35 \%$ \\
\hline \multicolumn{3}{|l|}{ Age } \\
\hline $18-30$ & 28 & $14 \%$ \\
\hline $31-45$ & 65 & $32 \%$ \\
\hline $46-60$ & 97 & $48 \%$ \\
\hline 61 or older & 13 & $6 \%$ \\
\hline
\end{tabular}

age was comparable: 18-30 years old (14\%), 31-45 years old (32\%), 46-60 years old (48\%), and 61 or older (6\%).

\section{Descriptive Analysis}

Table 2 presents descriptive analysis reporting means and standard deviations of variables on the survey. In general, respondents attended the festival for music-related reasons; this year's artists had a special appeal to them (mean score $=6.13$ out of a 7-point Likert scale), followed by the music in general motivated them to come to the festival (mean $=6.08$ ). The mean score for social motivation was relatively lower than music motivations (e.g., my motive for attending the festival is to join my friends/family (mean $=4.24)$. 
Table 2

Descriptive Analysis

\begin{tabular}{|c|c|c|c|}
\hline & Mean & SD & $\alpha$ \\
\hline Music motivation & & & 0.711 \\
\hline Jazz music is the motive for attending the festival & 5.65 & 1.41 & \\
\hline The music in general is my motive for attending the festival & 6.08 & 1.14 & \\
\hline This year's artists have a special appeal to me that motivates me to attend the festival & 6.13 & 1.13 & \\
\hline Social motivation & & & na \\
\hline My motive for attending the festival is to join my friends/family & 4.24 & 2.23 & \\
\hline Behavioral intention & & & 0.855 \\
\hline I have the intention of coming back to the festival & 6.26 & 1.11 & \\
\hline I will give good references of the festival to others & 6.51 & 0.71 & \\
\hline I will encourage my family and friends to come to the festival & 6.26 & 1.14 & \\
\hline I will consider the festival my first choice to attend a festival next year & 5.90 & 1.34 & \\
\hline I would recommend the festival to anyone that asks me & 6.50 & 0.85 & \\
\hline Satisfaction & & & na \\
\hline Overall, how satisfied were you with the services experienced at this festival? & 5.45 & 0.74 & \\
\hline
\end{tabular}

Note: Measured on a 7-point Likert scale.

The respondents shared higher behavioral intentions towards the festival. For example, the respondents would give good references of the festival to others (mean $=6.51$ ) and recommend the festival to anyone that asks me (mean $=6.50$ ). Lastly, the overall satisfaction level with the services at the festival was high (mean $=5.45$ ). The standard deviation ranged from 1.13 to 1.41 for music motivation and ranged from 0.71 to 1.34 for behavioral intention. The standard deviation for joining friends and family was reported 2.23 and for satisfaction was 0.74 . Reliabilities for music motivation and behavioral intention construct were assessed using Cronbach's alpha: music motivation $(\alpha=0.71)$ and behavioral intention $(\alpha=0.86)$.

\section{Female Motivation}

A $t$ test was conducted to examine the difference among the four motive scales between females and males. "Music in general" and "this year's artists" were significantly different with $t=3.20, p=0.08$ and $t=7.43, p=0.01$, respectively (Table 3 ). The findings suggested that males and females are differently motivated to attend the music festival in terms of general music and performers. Compared to male respondents, females are more likely to be motivated by music in general $\left(\mathrm{M}_{\mathrm{F}}=6.22 \mathrm{vs}\right.$. $\left.\mathrm{M}_{\mathrm{M}}=5.93\right)$ and performers $\left(\mathrm{M}_{\mathrm{F}}=6.33\right.$ vs. $\left.\mathrm{M}_{\mathrm{M}}=5.91\right)$. However, there was not a significant different social motivation between females and males.

\section{Biological Sex and Causal Relationships}

Several regressions were employed to assess the impact of biological sex on the relationship with motivation, satisfaction, and behavioral intentions (Table 4). In order to scrutinize the impact of biological sex, only music motivation items that differed between females and males were included in the analysis. In addition, an aggregated mean score of five behavioral intentions served as the dependent variable (model 2). Finally, the study disaggregated the behavioral intention construct and regressed two music motivations, satisfaction, and biological sex on each one of the five individual items comprising the construct behavioral intention (model 3-7). As a result, two proposed models revealed a significant moderating effect of biological sex on motivation, satisfaction, and loyalty.

Table 5 shows the three simultaneous regression analyses examining the moderating role of biological sex in relation to music motivations, satisfaction, and two loyalty items (i.e., "encourage family and friends to come to the festival" and "recommend the festival anyone that asks me"). The first regression examined the strength of association 
Table 3

Mean Differences on Motivations by Biological Sex

\begin{tabular}{|c|c|c|c|c|c|c|}
\hline \multirow[b]{2}{*}{ Motivation } & \multicolumn{2}{|c|}{ Male } & \multicolumn{2}{|c|}{ Female } & \multirow[b]{2}{*}{$t$} & \multirow[b]{2}{*}{ Sig. } \\
\hline & Mean & SD & Mean & SD & & \\
\hline \multirow{3}{*}{$\begin{array}{l}\text { Jazz music is the motive for attending the festival } \\
\text { The music in general is my motive for attending the festival } \\
\text { This year's artists have a special appeal to me that motivates me } \\
\text { to attend the festival }\end{array}$} & 5.56 & 1.45 & 5.72 & 1.37 & 0.71 & 0.40 \\
\hline & 5.93 & 1.29 & 6.22 & 0.98 & 3.20 & $0.08 *$ \\
\hline & 5.91 & 1.26 & 6.33 & 0.96 & 7.43 & $0.01^{* *}$ \\
\hline My motive for attending the festival is to join my friends/family & 4.15 & 2.17 & 4.32 & 2.29 & 0.28 & 0.60 \\
\hline
\end{tabular}

${ }^{*} p<0.10,{ }^{* *} p<0.05$.

between music motivations, satisfaction, and "encourage family and friends to come to the festival” (loyalty). The $R^{2}$ was 0.189 and the model was statistically significant with $F=15.661, p<0.001$. The motivation "music in general" and satisfaction significantly explained the variance of encouraging others to come to the festival. The implication is that general interests in music motivations and satisfaction have a positive impact on loyalty, encouraging others to come to the festival. In particular, the motivation "music in general" contributed more to the variance of loyalty $(\beta=0.310, p<0.001)$, compared to satisfaction $(\beta=0.193, p<0.05)$.

The second regression added the biological sex variable to the model. The model explained 21\% of the variation of the response variable. The beta for "music in general" was 0.320 , statistically significant at the 0.01 level, while satisfaction scored beta $=0.181$ at the 0.5 significance level. The effect of the variable "music in general" was stronger compared to satisfaction. Biological sex had a significant impact on loyalty $(\beta=-0.151, p<0.05)$. The results further indicated that female respondents appeared to be reluctant to encourage their family and friends to come to the festival.
Subsequently, the third regression assessed music motivations, satisfaction, and their interactions with biological sex on behavioral intention. The model explained $22.7 \%$ of the variation of the response variables. The interaction term between the motivation "music in general" and biological sex was found to be significant in explaining variance in loyalty ( $\beta=0.947, p<0.10$ ). In other words, compared to male respondents, females strengthened the impact of motivation "music in general" on loyalty by 0.947 for any increase of 1 point of motivation on a 7-point scale.

Another set of regression analyses was performed to detect the moderating impact of biological sex on music motivations, satisfaction, and "recommend the festival anyone that asks me" (Table 6). In the first regression, the strength of association between motivation, satisfaction, and "recommend the festival anyone that asks me" was investigated. Both music motivations and satisfaction significantly explained the variation of "recommend" (music in general: $\beta=0.348, p<0.001$; this year's artists: $\beta=0.163, p<0.05$; satisfaction: $\beta=0.223, p<0.05$ ). Positive relationships were found between motivations and satisfaction related to "recommend." The

Table 4

Regression Equations

\begin{tabular}{|c|c|}
\hline Regression Equations & Moderation Results \\
\hline (1) Satisfaction $=$ M1 + M2 + Sex + M1*Sex + M2*Sex & Not significant \\
\hline (2) Aggregated loyalty $=$ M1 + M2 + Sex + Sat + M1*Sex + M2*Sex + Sat*Sex & Not significant \\
\hline (3) Come back $=$ M1 + M2 + Sex + Sat + M1*Sex + M2*Sex + Sat*Sex & Not significant \\
\hline (4) First choice $=$ M1 + M2 + Sex + Sat + M1*Sex + M2*Sex + Sat*Sex & Not significant \\
\hline (5) Good reference $=$ M1 + M2 + Sex + Sat + M1*Sex + M2*Sex + Sat*Sex & Not significant \\
\hline (6) Recommend $=$ M1 + M2 + Sex + Sat + M1*Sex + M2*Sex + Sat*Sex & Significant \\
\hline (7) Encourage $=$ M1 + M2 + Sex + Sat + M1*Sex + M2*Sex + Sat $*$ Sex & Significant \\
\hline
\end{tabular}

Note: M1 = music in general; M2 = artists. 
Table 5

Moderating Effect of Biological Sex on the Relationships Among Motivations, Satisfaction and Loyalty (Encourage)

\begin{tabular}{|c|c|c|c|c|c|c|}
\hline \multirow[b]{2}{*}{ Independent Variables } & \multicolumn{2}{|c|}{ Step 1} & \multicolumn{2}{|c|}{ Step 2} & \multicolumn{2}{|c|}{ Step 3} \\
\hline & $\beta$ & $t$ & $\beta$ & $t$ & $\beta$ & $t$ \\
\hline Music in general & 0.310 & $4.154 * * *$ & 0.320 & $4.335^{* * * *}$ & -0.093 & -0.418 \\
\hline This year's artists & 0.025 & 0.341 & 0.052 & 0.713 & 0.148 & 0.674 \\
\hline Satisfaction & 0.193 & $2.785^{* *}$ & 0.181 & $2.630 * *$ & 0.420 & $1.904 *$ \\
\hline Biological sex & & & -0.151 & $-2.354 * *$ & -0.165 & -0.314 \\
\hline Biological sex * music in general & & & & & 0.947 & $1.953 *$ \\
\hline Biological sex * this year's artists & & & & & -0.240 & -0.479 \\
\hline Biological sex * satisfaction & & & & & -0.632 & -1.149 \\
\hline$F$ statistics & \multicolumn{2}{|c|}{$F(3,205)=15.661^{* * *}$} & \multicolumn{2}{|c|}{$F(4,205)=13.395^{* * *}$} & \multicolumn{2}{|c|}{$F(7,205)=8.311^{* * *}$} \\
\hline$R^{2}$ & \multirow{2}{*}{\multicolumn{2}{|c|}{$18.9 \%$}} & \multirow{2}{*}{\multicolumn{2}{|c|}{$21.0 \%$}} & \multicolumn{2}{|c|}{$22.7 \%$} \\
\hline DW & & & & & \multicolumn{2}{|c|}{1.862} \\
\hline
\end{tabular}

Note: Dependent variable denotes "encourage my family and friends to come to the festival."

$* * * p<0.001$.

more respondents were motivated for music in general and this year's artists, the more they recommend the festival to anyone that asked them.

The second regression model included biological sex as a separate variable. Music motivations and satisfaction significantly contributed to the variation of "recommend" (music in general: $\beta=0.352, p<$ 0.001 ; this year's artists: $\beta=0.173, p<0.05$; satisfaction: $\beta=0.218, p<0.05$ ). But biological sex was not found to be significant. In the last regression, the interaction terms were added to the model. The model explained $35.3 \%$ of the variation of the response variables. The motivation "music in general" and satisfaction had a significant positive impact on "recommend" (music in general: $\beta=0.338, p<0.10$; satisfaction: $\beta=0.598, p<0.05$ ). The more respondents were motivated for music in general, the more they recommend the festival "anyone that asks me." The interaction terms of satisfaction and biological sex was found to be significant in explaining variance in loyalty $(\beta=-1.007, p<0.05)$. Compared to male respondents, females weaken the impact of satisfaction on loyalty by 1.007 for any increase of 1 point of quality on a 7-point scale.

\section{Discussion}

The study examined two hypotheses: (1) females and males proffer distinct motivations, and (2) biological sex moderates the relationship between satisfaction and behavioral intentions at a music festival. The study confirms both hypotheses, revealing the

Table 6

Moderating Effect of Biological Sex on the Relationships Among Motivations, Satisfaction, and Loyalty (Recommend)

\begin{tabular}{|c|c|c|c|c|c|c|}
\hline \multirow[b]{2}{*}{ Independent Variables } & \multicolumn{2}{|c|}{ Step 1} & \multicolumn{2}{|c|}{ Step 2} & \multicolumn{2}{|c|}{ Step 3} \\
\hline & $\beta$ & $t$ & $\beta$ & $t$ & $\beta$ & $t$ \\
\hline Music in general & 0.348 & $5.136 * * *$ & 0.352 & $5.187 * * *$ & 0.338 & $1.659 *$ \\
\hline This year's artists & 0.163 & $2.454 * *$ & 0.173 & $2.582 * *$ & -0.139 & -0.692 \\
\hline Satisfaction & 0.223 & $3.535 * *$ & 0.218 & $3.449 * *$ & 0.598 & $2.963 * *$ \\
\hline Biological sex & & & -0.059 & -1.005 & 0.239 & 0.497 \\
\hline Biological sex $*$ music in general & & & & & 0.010 & 0.022 \\
\hline Biological sex * this year's artists & & & & & 0.750 & 1.638 \\
\hline Biological sex $*$ satisfaction & & & & & -1.007 & $-1.999 * *$ \\
\hline$F$ statistics & \multicolumn{2}{|c|}{$F(3,205)=33.301^{* * *}$} & \multicolumn{2}{|c|}{$F(4,205)=25.230 * * *$} & \multicolumn{2}{|c|}{$F(7,205)=15.417 * * *$} \\
\hline$R^{2}$ & \multirow{2}{*}{\multicolumn{2}{|c|}{$33.1 \%$}} & \multirow{2}{*}{\multicolumn{2}{|c|}{$33.4 \%$}} & \multicolumn{2}{|c|}{$35.3 \%$} \\
\hline DW & & & & & \multicolumn{2}{|c|}{2.02} \\
\hline
\end{tabular}

Note: Dependent variable denotes "recommend the festival anyone that asks me."

${ }^{*} p<0.10 ; * * p<0.05$; *** $p<0.001$. 
potency of biological sex as a relevant predictor in behavior. The results of this study give credence to the requirement of tapping the female segment by marketers of destination marketing. The importance of biological sex as a predictor of motivation and behavior combined with the growing number of the female segment will surely shape participation patterns in leisure and travel. These changing patterns may impact the current destination offerings and business practices. The tourism literature is slow in recognizing the importance of women as a separate segment.

The results also confirm one of the main tenets of women's development theory that females and males differ in their motivation and behavior with regard to their growth and development. There is a large body of studies grounded in the conceptual relational framework that posits that women are in search for connection to others as their main motive of their growth and development. The same body of literature asserts that men, on the other hand, search for status, distinctiveness, and separation. Understanding that females and males are different in motivation and behavior, and that their growth and development are potentially linked to different needs based on relation and separation, may result in a meaningful way as to how to promote a destination or event.

Another important finding of the study is that music is a powerful attractor of visitors to a destination. For example, $86 \%$ of attendees of the CNSJF visited the island of Curacao for the sole purpose of attending the music festival. Attendees scored a mean of 6.13 for the artists' line-up out of a 7-point Likert scale, followed by music in general with a mean score of 6.08 as what motivated them to come to the festival. Emphasizing music, therefore, as a strategic attribute to generate tourism demand may be meaningful in the context of small island destinations. In addition, the study suggests that females are more attuned to music and artists than males in attending a music festival. Compared to male respondents, females are more likely to be motivated by music in general $\left(M_{F}=6.22\right.$ vs. $\left.M_{M}=5.93\right)$ and performers $\left(\mathrm{M}_{\mathrm{F}}=6.33 \mathrm{vs}\right.$. $\left.\mathrm{M}_{\mathrm{M}}=5.91\right)$. This finding suggests that festival promoters should emphasize music and artists as key attractors to the female market. For example, festival organizers should take females' preferences into account as they design the artist line-up and the festival's program.
The study also suggests that motivation stimulates loyalty to the festival. The value of loyalty is an important consideration in destination management (Croes et al., 2010). However, consistent with the findings in the literature (Yoon \& Uysal, 2005), not all dimensions of motivation have an impact on loyalty. For example, the motive for music in general influences all dimensions of loyalty while the motive for seeking something to do at a destination does not have an impact on all dimensions of loyalty. Therefore, the focus of music as the main influence of loyalty is significant in building and sustaining the followers' base of a music festival.

The implications of the findings of the present study are threefold. First, the festival's managers should entertain a more refined approach to planning and marketing the festival, paying greater attention to biological make-up as a discriminant for segments. If biological make-up drives differences in motivation, transposing these differences into differentiated patterns of information processing becomes critical. It is crucial, however, that when transposing these messages that a balanced approach is considered in order not to completely isolate one segment. Combining the needs of both segments through activity and events, such as a music festival, as an opportunity for personal growth and development may generate a sustained drive for the activity and destination.

The second implication is the separation of the female from the male segment by framing and defining a music festival as an experience for personal growth and development. As the female segment becomes more relevant for festival managers, placing the proper messages in suitable manners and channels is crucial to the success of a music festival. This messaging and narratives should include more of the needs and aspirations of women (respect, identity, emotion, and connectivity) and less of the sexualized male gaze and surveillance, analyzed in the tourism literature. Intertwining and balancing the notions of connection (for the female market) and distinctiveness (for the male market) during an activity for personal growth (music festival) seems to be a powerful formula for festivals' marketers.

Finally, the third implication is that festival managers have an opportunity to accommodate the emerging demand from females with offerings and activities that emphasize their identity shaped by the need to 
connect to others through a music festival. Festival managers should deliver products and services catering to the special needs and aspirations of women. Noticeably, females have consistently shown favorable perceptions, at least in the case of this music festival, suggesting that music festivals could become a powerful avenue for women to enhance their identity by satisfying their deeper needs for connection. Festival managers should not only ensure that the information search experience prior to the festival is gratifying, but should create platforms that facilitates connectivity after the festival.

The study provides insights into how biological sex influences motivation and experiences, thereby providing clues how to differentiate among tourists. Biological sex as a predictor of motivation and behavior has wider implication than just increasing demand to a destination or event, however; it deeply shapes travel and leisure patterns as well, thereby potentially affecting offerings and practices. Consequently, activities that can help define femininity as an identity on its own terms may provide competitive advantages to an event and destination.

Future research should investigate whether festivals are a place for female identity building. The limitation of this study is its small sample size referencing one case. In addition, the study considered the female segment as a homogenous group. By interpreting the market in a dichotomous way, female versus male, the study may have missed the opportunity to look into the diversity of feminine subjects and the potential differences in tastes and experiences associated with that diversity. Future research will investigate the referenced diversity and its practical and theoretical implications.

\section{References}

Allen, J., O’Toole, W., McDonnell, I., \& Harris, R. (2002). Festival and special event management. Milton, Australia: Wiley.

Andreu, L., Kozac, M., Avci, N., \& Cifter, N. (2005). Market segmentation by motivations to travel: British tourists visiting Turkey. Journal of Travel \& Tourism Marketing, 19(1), 1-14.

Anderson, E., Fornell, C., \& Lehmann, D. (1994). Customer satisfaction, market share, and profitability: Findings from Sweden. Journal of Marketing, 58(3), 53-66.

Baker, D. A., \& Crompton, J. L. (2000). Quality, satisfaction and behavioral intentions. Annals of Tourism Research, 27(3), 785-804.
Barber, N., Taylor, D., \& Deale, C. S. (2010). Wine tourism, environmental concerns, and purchase intention. Journal of Travel \& Tourism Marketing, 27(2), 146-165.

Beerli, A., \& Marín, J. D. (2004). Tourists' characteristics and the perceived image of tourist destinations: A quantitative analysis - A case study of Lanzarote, Spain. Tourism Management, 25(5), 623-636.

Bowen, H. E., \& Daniels, M. J. (2005). Does the music matter? Motivations for attending a music festival. Event Management, 9, 155-164.

Brudney, D. (2002). Impact of women on travel. Palos Verdes, CA: ISHC and Hotel Online Report.

Central Bureau of Statistics. (2011). Stay over tourism data. Retrieved on October 6, 2013, from, http://www.cbs.cw /cbs/themes/Tourism/Data/Tourism-2014061640813.pdf

Change, J., \& Chiang, C. H. (2006). Segmenting American and Japanese tourists on no novelty-seeking at night markets in Taiwan. Asia Pacific Journal of Tourism Research, 11(4), 391-406.

Cockburn-Wootten, C., Friend, L., \& McIntosh, A. (2006). A discourse analysis of representational spaces: Writings of women independent traveller. Tourism, 54(1), 7-16.

Cole, S. T., \& Illum, S. F. (2006). Examining the mediating role of festival visitors' satisfaction in the relationship between service quality and behavioral intentions. Journal of Vacation Marketing, 12(2), 160-173.

Collins, D., \& Tisdell, C. (2002). Gender and differences in travel life cycles. Journal of Travel Research, 41(2), 133-143.

Craggs, R., \& Schofield, P. (2009). Expenditure-based segmentation and visitor profiling at the Quays in Salford, UK. Tourism Economics, 15(1), 243-260.

Croes, R. (2011). The small island paradox. Tourism specialization as a potential solution. Saarbrucken: Lambert Academic.

Croes, R., Rivera, M., \& Semrad, K. (2010). Uncovering the potential of a new and more affluent and loyal market: The Curacao North Sea Jazz Festival. Orlando, FL: The Dick Pope Sr. Institute for Tourism Studies.

Crompton, J. L. (1979). Motivations for pleasure vacation. Annals of Tourism Research, 6, 408-424.

Crompton, J. L., \& McKay, S. L. (1997). Motives of visitors attending festival events. Annals of Tourism Research, 24(2), 425-439.

Cronin, J. J., \& Taylor, S. A. (1992). Measuring service quality: A reexamination and extension. Journal of Marketing, 56(3), 55-68.

Dann, G. M. (1981). Tourism motivations: An appraisal. Annals of Tourism Research, 8(2), 189-219.

De Menezes, A., \& Moniz, A. (2011). Determinants of length of stay: A parametric survival analysis. Tourism Analysis, 16(5), 509-524.

Enloe, C. (1989). Bananas, bases and beaches. Making feminist sense of international politics. London: Pandora.

Faulkner, B., Fredline, E., Larson, M., \& Tomljenovic, R. (1999). A marketing analysis of Sweden's Storsjoyran music festival. Tourism Analysis, 4, 157-171. 
Florida, R. (2002). The rise of the creative class: And how it is transforming work, leisure, community, and everyday life. Basic Books: New York.

Formica, S., \& Uysal, M. (1996). A market segmentation of festival visitors: Umbria Jazz Festival in Italy. Festival Management \& Event Tourism, 3, 175-182.

Francese, P. (2004). Marriage drain's big cost. American Demographics, 26(3), 40-41.

Fullagar, S. (2002). Narratives of travel: Desire and the movement of feminine subjectivity. Leisure Studies, 21, 57-74.

Gelder, G., \& Robinson, P. (2009). A critical comparative study of visitor motivations for attending music festivals: A case study of Glastonbury and V festival. Event Management, 13, 181-196.

Getz, D. (1991). Festivals, special events, and tourism. New York: Van Nostrand Reinhold.

Getz, D. (1993). Festivals and special events. In M. A. Khan, M. D. Olsen, \& T. Var (Eds.), Encyclopedia of hospitality and tourism (pp. 789-810). New York: Van Nostrand Reinhold.

Getz, D. (2010). The nature and scope of festival studies. International Journal of Events Management Research, 5(1), 1-47.

Gibson, H. (2005). Towards an understanding of 'Why sport tourists do what they do.' Sport in Society, 8(2), 198-217.

Gnoth, J. (1997). Tourism motivation and expectation formation. Annals of Tourism Research, 24(2), 283-304.

Graburn, N., \& Jafar, J. (1991). Introduction: Tourism social science. Annals of Tourism Research, 18, 1-11.

Griskevicius, V., \& Kenrick, D. T. (2013). Fundamental motives for why we buy: How evolutionary needs influence consumer behavior. Journal of Consumer Psychology, 1-47.

Gursoy, D., Kim, K., \& Uysal, M. (2004). Perceived impacts of festivals and special events by organizers: An extension and validation. Tourism Management, 25(2), 171-181.

Hair, J. F., Black, W. C., Babin, B. J., \& Anderson, R. E. (2010). Multivariate data analysis. Upper Saddle River, NJ: Pearson Prentice Hall.

Hallab, Z., Price, C., \& Fourniert, H. (2006). Students' travel motivations. Tourism Analysis, 11(2), 137-142.

Hinch, T., \& Walker, G. J. (2005). Casino markets: A study of tourist and local patrons. Tourism \& Hospitality Research, 6(1), 72-87.

Irigaray, L. (1993). An ethics of sexual difference. Ithaca, NY: Cornell University Press.

Ignatov, E., \& Smith, S. (2006). Segmenting Canadian culinary tourists. Current Issues in Tourism, 9(3), 235-255.

Iso-Ahola, S. (1982). Toward a social psychology theory of tourism motivation. Annals of Tourism Research, 12, 256-262.

Jensen, J. M. (2011). The relationships between sociodemographic variables, travel motivations and subsequent choice of vacation. In Proceedings of the 2nd International Conference on Economics, Business and Management, IPEDR, Vol. 22 (pp. 37-44). Singapore: IACSIT Press.
Jönsson, C., \& Devonish, D. (2008). Does nationality, gender, and age affect travel motivation? A case of visitors to the Caribbean Island of Barbados. Travel \& Tourism Marketing, 25(3/4), 398-408.

Kerlinger, F. N. (1992). Foundations of behavioural research. New York: Holt, Rinehart, and Winston.

Kim, D., Lehto, X., \& Morrison, A. (2007). Gender differences in on-line travel information search: Implications for marketing communications on the Internet. Tourism Management, 28, 423-433.

Kollmuss, A., \& Agyeman, J. (2002). Mind the gap: Why do people act environmentally and what are the barriers to pro-environmental behavior? Environmental Education Research, 8(3), 239-260.

Lee, C. K., \& Lee, T. H. (2001). World Culture EXPO segment characteristics. Annals of Tourism Research, 28(3), 812-816.

Lee, C. K., Lee, Y. K., \& Wicks, B. E. (2004). Segmentation of festival motivation by nationality and satisfaction. Tourism Management, 25(1), 61-70.

Lee, S. Y., Petrick, J. F., \& Crompton, J. (2007). The roles of quality and intermediary constructs in determining festival attendees' behavioral intention. Journal of Travel Research, 45(4), 402-412.

Leenders, M. A. (2010). The relative importance of the brand of music festivals: A customer equity perspective. Journal of Strategic Marketing, 18(4), 291-301.

Li, M., Wen. T., \& Leung, A. (2011). An exploratory study of the travel motivation of Chinese female outbound tourists. Journal of China Tourism Research, 7(4), 411-424.

Marzo-Navarro, M., \& Pedraja-Iglesias, M. (2009). Profile of a wine tourist and the correspondence between destination and preferred wine: A study in Aragon, Spain. Journal of Travel \& Tourism Marketing, 26(7), 670-687.

McGehee, N. G., Loker-Murphy, L., \& Uysal, M. (1996). The Australian international pleasure travel market: Motivations from a gendered perspective. The Journal of Tourism Studies, 7(1), 45-57.

McNamara, K., \& Prideaux, B. (2010). A typology of solo independent women travellers. International Journal of Tourism Research, 12(3), 253-264.

Michaelson, C. (2005). Meaningful motivation for work motivation theory. Academy of Management Review, 30(2), 235-238.

Miller, J. B. (1976). Toward a new psychology of women. Boston: Beacon Press.

Mohr, K., Backman, K. F., Gahan, L. W., \& Backman, S. J. (1993). An investigation of festival motivations and event satisfaction by visitor type. Festival Management \& Event Tourism, 1, 89-97.

Mohsin, A. (2008). Analysis of Chinese travellers' attitudes toward holidaying in New Zealand: The impact of sociodemographic variables. Journal of Hospitality \& Leisure Marketing, 16(1/2), 21-40.

Nicholson, R. E., \& Pearce, D. G. (2001). Why do people attend events: A comparative analysis of visitor motivations at four South Island events. Journal of Travel Research, 39(4), 449-460. 
Nitto, H., \& Shiozaki, J. (2001). Changing consumption patterns and new lifestyles in the 21st century. Nomura Research Institute (NRI) Papers, No. 24. Retrieved from https://www.nri.com/global/opinion/papers/2001/pdf /np200124.pdf

Oakes, S. (2003). Demographic and sponsorship considerations for jazz and classical music festivals. The Services Industries Journal, 23(3), 165-178.

Oppermann, M. (2000). Tourism destination loyalty. Journal of Travel Research, 39, 78-84.

Palan, K. M. (2001). Gender identity in consumer behavior research: A literature review and research agenda. Academy of Marketing Science, 2001(10), 1-31.

Pegg, S., \& Patterson, I. (2010). Rethinking music festivals as a staged event: Gaining insights from understanding visitor motivations and the experiences they seek. Journal of Convention \& Event Tourism, 11(2), 85-99.

Plangmarn, A., Mujtaba, B. G., \& Pirani, M. (2012). Cultural value and travel motivation of European tourists. The Journal of Applied Business Research, 28(6), 1295-1304.

Pritchard, A., \& Morgan, N. (2000). Constructing tourism landscapes-Gender, sexuality and space. Tourism Geographies, 2(2), 115-139.

Reisinger, Y., \& Mavondo, F. (2004). Exploring the relationships among psychographic factors in the female and male youth travel market. Tourism Review International, 8(2), 69-84.

Reynolds, Z., \& Hritz, N. M. (2012). Surfing as adventure travel: Motivations and lifestyles. Journal of Tourism Insights, 3(1), 2.

Richards, G. (2010). Leisure in the network society: From pseudo-events to hyperfestivity? Tilburg, the Netherlands: Tilburg University Press.

Saleh, F., \& Ryan, C. (1993). Jazz and Knitwear: Factors that attract tourists to festivals. Tourism Management, 14(4), 289-297.

Schneider, I. E., \& Backman, S. J. (1996). Cross-cultural equivalence of festival motivations: A study in Jordan. Festival Management \& Event Tourism, 4(3/4), 3-4.

Schofield, P., \& Thompson, K. (2007). Visitor motivation, satisfaction and behavioural intention: The 2005 Naadam Festival, Ulaanbaatar. International Journal of Tourism Research, 9, 329-344.

Scott, D. (1996). A comparison of visitors' motivation to attend three urban festivals. Festival Management \& Event Tourism, 3(3), 121-128.
Silverstein, M. J., \& Sayre, T. K. (2009). Women want more: How to capture your share of the world's largest market. New York: HarperCollins.

Smith, S., \& Costello, C. (2009). Culinary tourism: Satisfaction with a culinary event utilizing importance-performance grid analysis. Journal of Vacation Marketing, 15(2), 99-110.

Staggenborg, S., Eder, D., \& Sudderth, L. (1994). Women's culture and social change: Evidence from the national women's music festival. Berkeley Journal of Sociology, 38, 31-56.

Thrane, C. (2002). Jazz festival visitors and their expenditures: Linking spending patterns to musical interest. Journal of Travel Research, 40(3), 281-286.

Tkaczynski, A., \& Prebensen, N. K. (2012). French naturebased tourist potentials to Norway: Who are they? Tourism Analysis, 17(2), 181-193.

Ulrich, I. (2013). The effect of consumer multifactorial gender and biological sex on the evaluation of cross-gender brand extensions. Psychology and Marketing, 30(9), 794-810.

Uysal, M., Gahan, L., \& Martin, B. (1993). An examination of event motivations: A case study. Festival Management \& Event Tourism, 1(1), 5-10.

Van Zyl, C., \& Botha, C. (2004). Motivational factors of local residents to attend the Aardklop National Arts Festival. Event Management, 8(4), 213-222.

Warnick, R. B., \& Chen, M. (2008). Female travel trends: A look back to the future. Tourism Review International, 12(2), 138-164.

Woo, E., Yolal, M., Cetinel, F., \& Uysal, M. (2011). A comparative study of motivation across different festival products. Paper presented at the $16^{\text {th }}$ Graduate Students Research Conference, Houston, Texas, January 6-8.

World Bank. (2011). Curacao world development indicators. Retrieved March 2, 2015, from, http://data.world bank.org/country/CW\#cp_wdi

Yolal, M., Cetinel, F., \& Uysal, M. (2009). An examination of festival motivation and perceived benefits relationship: Eskisehir International Festival. Journal of Convention \& Event Tourism, 10, 276-291.

Yoon, Y., \& Uysal, M. (2005). An examination of the effects of motivation and satisfaction on destination loyalty: A structural model. Tourism Management, 26(1), 45-56.

Zeithaml, V. A., Berry, L. L., \& Parasuraman, A. (1996). The behavioral consequences of service quality. Journal of Marketing, 60(2), 31-46. 